\title{
Teaching English to Saudi Police Cadets: An Evaluation Study
}

\author{
Mohammed Nasser Alhuqbani \\ Department of Languages \& Translation, King Fahd Security College, Riyadh, Saudi Arabia
}

\begin{abstract}
This study evaluated the teaching of English to Saudi police cadets at King Fahd Security College in Riyadh, Saudi Arabia. The participants included three groups of stakeholders: six English teachers, sixteen former police cadets and 122 current police cades. Data collection instruments included a set of three short questionnaires and observation. The analysis of the results showed that the ESP course and teaching at KFSC is ineffective and inappropriate due to administrative and methodological factors. The current ESP course lacks the major principles associated with the teaching of English for specific purposes such as meeting the police cadets' actual needs and turning these needs into operational objectives that can be tested. Administratively, the three groups of stakeholders expressed their dissatisfaction with the course duration and timing. The study concludes with some important pedagogical implications for the improvement of the ESP course and teaching at KFSC.
\end{abstract}

Index Terms-ESP, evaluation, King Fahd Security College, police cadets

\section{INTRODUCTION}

Today, the need for English as a foreign language has brought about a significant adjustment in the requirements of many educational systems, including police education. Thus, evaluation plays an important role in language education in general and ESP in particular since it answers various questions related to the feasibility and quality of English teaching courses and programs in terms of achieving the learning objectives and bringing about the intended outcome. However, despite the fact that evaluation is an indispensible tool in language education, it is still an overlooked area in both language teaching and research, especially in military and police contexts. Therefore, this study attempted to evaluate the ESP course used to teach English to police cadets at King Fahd Security College (hereafter KFSC).

\section{LITERATURE REVIEW}

\section{A. Definition and Types of Evaluation}

Evaluation in language education has been defined in a verity of ways. For example, Richards et al. (1985, p. 130) defined it as "the systematic gathering of information for purposes of making decisions." Similarly, Lynch (1996, p.2) defined evaluation as "the systematic attempt to gather information in order to make judgments or decisions." These two definitions are too broad since they made no direct reference to evaluation as both a process and a product. Moreover, both definitions could be equally used to define needs analysis, where the difference between the two "may be more of focus than of the actual activities involved" (Brown, 1989, p. 223). Since these two definitions were too broad, other researchers provided definitions of evaluation to include more information of it as a process and a product. For instance, Brown (1989, p. 223) defined it as "the systematic collection and analysis of all relevant information necessary to promote the improvement of a curriculum, and assess its effectiveness and efficiency, as well as the participants' attitudes within a context of particular institutions involved." This definition shows that evaluation is not only a systematic collection of information, but also a systematic analysis and assessment of these information with the aim to improve the efficiency of a curriculum in the light of the concerned parties within a particular institution. In the same manner, Patton (1997, p.23) defined evaluation as "the systematic collection of information about the activities, characteristics, and outcomes of programs to make judgments about the program, improve program effectiveness, and/or inform decisions about future programming."

With regard to types of evaluation, there are two types commonly used in language education: formative and summative (Richards, 2001). The former is carried out while the course is ongoing and the results of it can be used to amend what is wrong with the course. The information collected in a formative evaluation guides the teacher's decisions as the course continues. In contrast, the latter is administered and completed when the course ends and the instructor or evaluator collects information about the learners' achievements and the effectiveness of the course. A summative evaluation helps stakeholders, including administrators and teachers, to view the progress of the program and provides an opportunity for the evaluators to view the program as a whole, and base their decisions to continue or discontinue the program on solid information.

B. Evaluation Framework in ESP 
ESP is an approach that has grown to become an important branch of English language teaching since the 1960s. Unlike English for general purposes, ESP views its learners as adult learners who are fully aware that they are learning the target language for utilitarian purposes (Robinson, 1991); and therefore, there is a need for assessing their achievement in both language skills and their area of the study; thus, ESP courses are mainly designed to help learners perform particular communicative tasks related to a particular sitting (e.g., business, police, aviation, etc). Hence evaluation becomes one of the major aspects in ESP.

In an early study on the role of evaluation in ESP, Batchman (1981) drew an important distinction between two levels of evaluation: micro-evaluation and macro-evaluation. In the former, decisions are made regarding individuals in the ESP program, including the students, teachers and administrators. Students are assessed in terms of their readiness for the ESP program and the acceptability of their achievement to teachers, administrators, peers and prospective employers. In the latter, decisions are made to determine the effectiveness and acceptability of the ESP program as a whole. Batchman emphasized that the two levels are not necessarily independent of each other.

Despite that their evaluation framework is "somewhat dated" (Tsou \& Chen, 2014, p. 39), Hutchinson and Waters' (1987) developed a useful ESP program evaluation consisting of two levels: learner assessment and course evaluation. Their evaluation model is similar to Batchman's (1981) model. They argued that learner assessment is of a greater importance in ESP because it is concerned with the ability of the learner to perform particular communicative tasks in certain situations, which can be measured through using various tests such as placement tests, achievement tests and proficiency test. As its name shows, course evaluation is mainly concerned with whether an ESP course is doing what it is designed to do. It shows that the involved shareholders' views (i.e. teachers, learners, sponsors, etc.) are very important in the evaluation process of an ESP program.

More recently, Tsou and Chen (2014) proposed an ESP evaluation framework that looks beyond learner assessment and course evaluation. Their proposed framework consists of at least three components: course evaluation, learner assessment and teacher participation and empowerment. Tsou and Chen adopted the first two parts from Hutchinson and Waters' model and the third part from the foreign language (FL) program evaluation model developed by Watanabe et al. (as cited in Tsou and Chen, 2014). Unlike these two models, Tsou and Chen's model emphasizes gaining insights into certain aspects of an ESP program that have not been mentioned in previous models of ESP program evaluation such as materials authenticity, learner autonomy, and learning transfer. Like the FL program evaluation model, Tsou and Chen stressed the importance of beginning the evaluation process by identifying the stakeholders' needs and goals. Examples of the stakeholders of an ESP program include sponsors, course developers, instructors and students. The outcomes of the evaluation framework assist stakeholders to determine the effectiveness of an ESP program and to identify the adjustment or improvement of the course design and instruction. However, it is the teacher participation and empowerment component that makes Tsou and Chen's model a powerful one. This component can be accessed through utilizing teacher surveys and interviews. It can help obtain feedback from teachers about whether the organization provides supportive and independent climate, whether teachers are aware of the aim of the ESP program, whether teachers have a say on how the program was run and how they are being evaluated, and finally whether teachers and program administrators have regular meetings to discuss and negotiate any difference. As Tsou and Chen admitted, this evaluation framework suffers from some limitations. The most important of all is the difficulty to implement all these components at once. Therefore, they suggested prioritizing the components, either by importance or by how easy is it to measure the results.

\section{Studies Related to Evaluation in ESP}

The majority of ESP studies focused on learners' needs analysis in various ESP contexts such as engineering (e.g., Hossain. 2013), police (e.g., Qaddomi, 2013) and medicine (e.g., Hwang \& Lin, 2010) and textbooks evaluation (e.g., El-Sakran, 2012; Ghalandari \& Talebinejad, 2012; Sarem et al., 2013). In contrast, there are few and scattered evaluation studies regarding the stakeholders' views of ESP programs such as teachers, formers students, administrators, etc. Some of these studies are briefly reviewed below.

Munisamy (1997) conducted a formative evaluation of the syllabus for English for commercial purposes at a Malaysian university to determine its effectiveness. The participants were English teachers, subject teachers, final year commerce students and former students. The results showed some weaknesses in the ESP program and its implementation. For example, there was no connection between the skills taught in the classroom and certain job skills. He concluded that these weaknesses should be treated, so that the ESP program can be more effective in achieving its objectives.

In another study, Kuppan (2008) evaluated whether the hospitality management course at a Malaysian university is consistent with the English needs of the students in terms of course objectives, course content, teaching and learning materials, teaching methodology, time allocation and evaluation system. The participants were four teachers and sixty students. The researcher used three different sets of questionnaires and interviews. The findings showed some weaknesses in the course in terms of course content, usage of materials and teaching methodology. There was also a gap between the skills taught in the course and hospitality management skills. Kuppan concluded that there is a need to revise some aspects of the course based on both the current needs of the students and the hospitality industry.

Thompson (2011) evaluated an English course for tourism program at a Thai university. The participants were fifteen students, two university officials, and the instructor of the course. He collected data through a questionnaire, interviews, 
a teacher's log, and learning materials. The results showed that the learners responded positively to in-class listening and speaking tasks that they felt manageable and relevant to their future jobs. However, there were negative responses towards textbook and outside readings. The learners viewed them as unimportant to their goals. In addition, the two officials and the instructor viewed the program as a vital part of the curriculum, but felt that the learners' backgrounds were hindering the overall program development.

Barnawi (2011) examined the usefulness of formative evaluation in providing data for the Arabian Industrial College ESP program. He focused on the perspectives of three groups of stakeholders: ESP teachers, students and former students. He collected data through a survey, semi-structured interviews and program-related document analysis. The results indicated that using a formative approach to evaluate an ESP program would not only help educators identify strengths of their language programs and reinforce those strengths, but would also help them examine practices and policies.

Finally, in a more recent study, Sarudin et al. (2013) investigated the stakeholders' perceptions of the strengths and weaknesses of an ESP course for students of economics and management science at a Malaysian university. A total of 177 participants (undergraduate students, instructors and administrators) took part in the study. The instruments included questionnaires and semi-structured interviews. The findings showed that the three groups of participants were in general satisfied with the ESP course. However, there were some shortcomings in the ESP course that need to be adjusted such as methods of teaching and oral and written communication skills related to job application.

\section{Conclusion}

As seen above, a few evaluation studies have been conducted within the framework of ESP. None of these studies has been carried out within the context of police, which makes conducting this study a very important project. The few police studies conducted so far have focused on identifying the English languages of police cadets or officers (e.g., Alhuqbani, 2008; 2014; Qaddomi, 2013) or on police officers' motivation and attitudes toward learning English (e.g., Alhuqbani, 2009; Alqurashi, 2011). Therefore this study attempts to bridge this gap in the literature by evaluating the stakeholders' perceptions of the ESP course and teaching at KFSC.

\section{RESEARCH PROBLEM}

English has been taught to Saudi police cadets at KFSC since the 1960s which shows the early awareness of the importance of teaching English to police cadets in Saudi Arabia (Alhuqbani, 2014). In the last two decades, the teaching of English at KFSC has gone through three phases. According to Aldossari (1999), English was taught intensively to the cadets in the 1990s. They had six hours of English instructions per week and for three uninterrupted years. The cadets were taught a series of three textbooks titled Special English Course for Police Cadets developed by instructors in the English Department. Aldossari (1999) described English teaching in this phase as lacking important factors that should be available in a successful ESP course such as basing the course content on the cades' actual English needs, defining learning objectives and including authentic materials. In the second phase 2000-2008, the amount of English instruction was sharply reduced to just two hours per week and for one semester. The assigned textbook during this period was a general one titled New Interchange. In the current phase starting from 2009 up to now, English continued to be taught for only two hours per week in the last semester, and only for police cadets with university degrees in humanities (Alhuqbani, 2014). However, teaching emphasis has been switched to teaching English for security purposes, reflecting the growing need to teach police cadets materials related to their future police tasks. The assigned textbook was English for Security Purposes: Book One ( $2^{\text {nd }}$ edition, 2012) by M. Alhuqbani who based the content of this textbook on the results of his studies of Saudi police officers' English needs (2008) and motivations and attitudes (2009). Some of these changes, especially those ones related to the course duration and timing, took place at KFSC without taking into account the opinions of important parties such as English instructors, former police cadets and current police cadets. According to Weir and Roberts (1994), different stakeholders such as instructors and students should participate in program evaluation because a single evaluator many not be able to provide a comprehensive evaluation of the course or program under question. Therefore, this study attempted to find out how these three groups view the ESP course and teaching at KFSC and how their opinions can be used to improve the teaching of English for security purposes at KFSC.

\section{PURPOSE OF THE STUDY}

The main purpose of the study was to evaluate the appropriateness and effectiveness of the English course and teaching at KFSC through the perspectives of teachers, current police cadets and former police cadets in terms of program density of hours, length, objectives, content and target learners. Additionally, this study aimed to suggest relevant adaptations and contribute to the improvement of the teaching of English to police cadets at KFSC.

\section{SignificAnCE OF THE StUdy}

To the best knowledge of the researcher, there are no evaluation studies in the context of teaching English for police purposes in the ESP literature. In light of this, it is important to assess the effectiveness and adequacy of the English ESP course at KFSC, which is developed for Saudi police cadets. The findings of this study will help increase the body 
of knowledge that is available in terms of ESP course design, materials and teaching methodology pertaining to police cadets. It is also hoped that the findings of this study will inform educators and decision makers at KFSC about the characteristics of the current English course and teaching as viewed by teachers, current and previous police cadets. Therefore, this study will help KFSC policy makers to find out how effective the current English teaching course is, along with identifying the strengths and weaknesses of the course, if there are any. This evaluation study will also help administrators at KFSC make relevant changes and additions to the current ESP course. It is hoped that the results of the study will provide valuable insights into the effectiveness of the English course and be used as a framework for the improvement of English teaching at KFSC.

\section{RESEARCH QUESTIONS}

The study addressed the following two related research questions:

1. How do teachers, former police cadets and current police cadets view the ESP course and teaching at KFSC?

2. What are the pedagogical implications of the research findings to the teaching of English at KFSC?

\section{METHOD}

\section{A. Participants}

In order to obtain a wide range of diverse and sometimes contradictory views on the teaching of English at KFSC, the study focused on three types of participants: six English teachers, 16 former police cadets, and 122 current police cadets. The teachers were five Saudis and one Jordanian. Four of them have masters' degrees in English teaching and two have masters' degrees in translation studies. Three of them have been teaching English at KFSC for more than 20 years. One teacher has been teaching English at the college for seven years. Two teachers started teaching English at the college two years ago. The sixteen former police cadets joined the college as first lieutenants this year after graduating from KFSC with a diploma in security sciences. They originally have bachelor degrees in various fields such as computer sciences and law. Fifty-two of the current police cadets were drawn from a class in the one-year diploma program, which is designed for university students with bachelor degrees in sciences. Seventy cadets were in the two-year diploma program, which is geared for university students with bachelor degrees in humanities.

\section{B. Instruments}

\section{Questionnaire}

Both quantitative and qualitative methodologies were adopted in this study. Quantitative data were collected by means of a short questionnaire developed by the researcher for each group. The teachers' questionnaire included fifteen statements. The former police cades' questionnaire consisted of twelve statements. The current police cadets' questionnaire included seven statements. The statements in each questionnaire described the participants' opinion about the teaching of English to police cadets at KFSC. There were some statements repeated in each questionnaire because they sought the opinion of the three types of participants on the same matter. The three questionnaires were written and introduced in Arabic in order to get more accurate data from the participants and avoid confusion. Each questionnaire was pilot tested with two participants from each group, not involved in the study, to ensure clarity in the statements. Overall, the participants found the statements in the three short questionnaires comprehensible and easy to score.

\section{Observation}

Descriptive data was collected by observing the way English is taught at KFSC. The researcher, who has been teaching and supervising English at KFSC since 2004, wrote down his daily observation of what others say about teaching English at KFSC including teachers, previous cadets, on-the-job officers and some administrators. The observed data was exclusively used in this study to aid the interpretation of the data collected via the three questionnaires described above.

\section{Data Collection and Analysis Procedures}

The researcher collected data through three different means. For the English teachers, the researcher emailed the questionnaire to them and solicited them to answer it and email it back within one week. The current cadets received the questionnaire in their classes through their instructors. Similarly, the former police cadets, who joined KFSC in 2013 as $1^{\text {st }}$ lieutenant officers, received their questionnaire during one of their preparatory classes which they were required to take. All the three groups received the questionnaires in the first semester of the academic year 2013/2014, except 25 cadets who were drawn from a class in the second semester in which English is taught to the cadets in the two-year security diploma. The Statistical Package for the Social Sciences (SPSS) program was employed to analyze the data. The participants' responses to the questionnaire items were coded as follows: strongly agree - 5, agree - 4, strongly disagree - 3, disagree - 2, uncertain - 1 . The frequencies, means, percentages, and standard deviations for the questionnaire items were demonstrated in tables. A t-test was used to compare the two current groups of cadets' opinion on statements that were similar. The cadets were classified into two groups: cadets with university degrees in humanities versus cadets with degrees in science. Furthermore, a one way ANOVA test was used to examine the three 
participants' (teachers, current cadets, recent police graduates) opinion on statements that were similar across the three questionnaires.

\section{RESULTS}

\section{A. Teachers' Perspectives}

Table 1 below presents the percentages of the six teachers' perspectives of the English course and English teaching at KFSC.

TABLE 1.

PERCENTAGES OF TEACHERS' PERSPECTIVES OF TEACHING ENGLISH AT KFSC

\begin{tabular}{|c|c|c|c|c|c|}
\hline Questionnaire Statements & SA & A & SD & $\mathrm{D}$ & $\mathrm{UC}$ \\
\hline 1. The college's objectives for teaching English are clear and written down. & 16.7 & 33.3 & 33.3 & 16.7 & \\
\hline 2. Teaching English for two hours per week is sufficient for the college's cadets. & & 16.7 & 66.7 & & 16.7 \\
\hline 3. Teaching English for one semester is enough for the college's cadets. & & 33.3 & 66.7 & & \\
\hline $\begin{array}{l}\text { 4. General objectives of teaching English to the cadets must be formulated and made available } \\
\text { to teachers }\end{array}$ & 50 & 50 & & & \\
\hline $\begin{array}{l}\text { 5. Increasing the number of hours for teaching English is necessary for the college cadets, so } \\
\text { that they can use English in their security jobs }\end{array}$ & 50 & 16.7 & & & 33.3 \\
\hline $\begin{array}{l}\text { 6. English should be taught to the college's cadets in the first and second semester in every } \\
\text { academic year. }\end{array}$ & 33.3 & 33.3 & & 16.7 & 16.7 \\
\hline $\begin{array}{l}\text { 7. There is a periodical evaluation of the English language program to determine its } \\
\text { appropriateness and objectives achievement }\end{array}$ & & 16.7 & 33.3 & 33.3 & 16.7 \\
\hline 8. There is a positive interaction between the cadets and the current English course. & & & 50 & 50 & \\
\hline $\begin{array}{l}\text { 9. The general content of the English program is consistent with the cadets' needs for English for } \\
\text { security Purposes }\end{array}$ & 16.7 & 33.3 & & 33.3 & 16.7 \\
\hline $\begin{array}{l}\text { 10.Teaching English in the college does not receive clear and practical support from those in } \\
\text { charge of education in the college }\end{array}$ & 66.7 & & 16.7 & 16.7 & \\
\hline $\begin{array}{l}\text { 11. There false beliefs inside the college weakened the teaching of English such as English is not } \\
\text { important to the college cadets, the college is not the right environment to learn English, etc }\end{array}$ & 66.7 & & & & 33.3 \\
\hline $\begin{array}{l}\text { 12. The current teaching of English in the college is weak in general due to the absence of the } \\
\text { necessary ingredients for its success }\end{array}$ & 100 & & & & \\
\hline $\begin{array}{l}\text { 13. During my teaching I observed that the cadets suffered from the limited hours assigned to } \\
\text { English teaching, and they asked increase of the number of hours, so that they can improve their } \\
\text { English proficiency level }\end{array}$ & 33.3 & 16.7 & 33.3 & & 16.7 \\
\hline $\begin{array}{l}\text { 14. Limiting the teaching of English for security purposes to cadets with degrees in humanities } \\
\text { means that half of the college's cadets with science degrees graduate with no training on how to } \\
\text { use English for security purposes. }\end{array}$ & 33.3 & 50 & & 16.7 & \\
\hline $\begin{array}{l}\text { 15. The current English teaching (the number of hours and its duration) was suggested by the } \\
\text { English teachers and was employed accordingly by the education policy makers in the college. }\end{array}$ & & & 33.3 & & 66.7 \\
\hline
\end{tabular}

The analysis of the results showed that the teachers seem to be equally divided with regard to statement no.1: the clarity and availability of the college's objectives for teaching English to its cadets. The teachers, who strongly disagreed with this statement, had experience over 20 years in teaching English at KFSC, whereas two of the other three teachers who agreed to this statement had experience of less than two years in teaching English at KFSC. The teachers' divided opinion over the clarity and availability of learning objectives disappear in their responses to statement no. 4. All the teachers either strongly agreed or just agreed that general objectives of teaching English to the cadets must be formulated and made known to the teachers.

With regard to the duration of the English course as expressed in statements no. 2 and 3, the majority of the teachers $(66.7 \%)$ strongly disagreed with teaching English for just two hours per week. Therefore, more than half of the teachers $(66.7 \%)$ agreed that increasing the number of hours for teaching English would help the cadets practice and use English in their future security sectors. Since increasing the hours of English teaching requires more space on the timetable, $66.6 \%$ of the teachers agreed that teaching English should take place not only in the second semester of the final year, but also in the first semester in every academic year.

It is not surprising, however, that the inadequacy of the current English course and teaching at KFSC has gone unnoticed for a long time because, as the majority of teachers $(66.6 \%)$ pointed out, there is no periodical evaluation of the English teaching. For this reason and among others, all the six teachers (100\%) indicated that there was no positive interaction between the cadets and the current English course and teaching. This may explain why the majority of the teachers $(66.7 \%)$ say that teaching English in the college does not receive clear and practical support from the college administration. Other factors may also have contributed to this lack of interaction between the cadets and the current English course. For example, more than half of the teachers (66.7\%) agreed that false beliefs inside the college such as English is not important to the college cadets and the college is not the right environment to learn English have weakened the teaching of English at the college. Another factor may include what all the six teachers (100\%) agreed to is that the current teaching of English in the college is weak in general due to the absence of the necessary requirements for success. For example, half of the teachers (50\%) disagreed with the limited hours (two hours) assigned to English teaching in the college. 
Despite their description of the current ESP program and teaching as generally weak, half of the teachers (50\%) agreed that the general content of this course is consistent with the cadets' needs for English for security Purposes. The content of this course is based on police related topics and activities.

Teaching English for security purposes to one group of cadets at the college is rejected by the majority of the teachers $(83.3 \%)$, whose opinion is that limiting the teaching of English for security purposes to cadets with university degrees in humanities would exclude half of the college's police cadets with science degrees from receiving training on how to use English for security purposes.

Finally, the majority of the teachers $(66.7 \%)$ are uncertain about who suggested the current English teaching in terms of the course duration and its timing. In fact, $33.3 \%$ of the teachers denied that this course was suggested by them.

\section{B. Former Police Cadets' Perspectives}

One of the most important sources of information in language course evaluation is former students' feedback because they have experienced its advantages and disadvantages. Table 2 below summarizes the former police cadets' evaluation of the current English course and teaching at KFSC. The majority of the former police cadets (62.5\%) disagreed with teaching English for two hours per week as shown in statements no. 1. Similarly, $66.6 \%$ of the former police cadets disagreed with teaching English for one semester as mentioned in statement no. 2. To affirm their attitude towards statements no. 1 and 2, more than half of the former police cadets $(60 \%)$ agreed to increasing the number of hours for teaching English at KFSC, and 53.3\% agreed to teaching English in the first and second semester in every academic year. With regard to the interaction between the former cadets and the current English course, they seem to be divided in their opinions. However, half of them (50\%) disagreed with the content of statement no. 5 and indicated that there was no interaction between them and the current English course. Twenty-five percent of the former police cadets agreed that there was positive interaction, and the other 25 percent were uncertain. When asked about whether the general content of the English course is consistent with the cadets' needs for English for security purposes, the majority of the former cadets $(81.3 \%)$ agreed to that. Similar to the teacher's opinion, half of the former police cadets $(50.1 \%)$ agreed that English teaching in the college does not receive tangible support from the college administration. That is why the majority of the former cadets $(68.8 \%)$ described the current English course as generally weak because it does not meet the requirements associated with successful language courses. To get their feedback about which group of police cadets should be taught English at KFSC, more than half of the former cadets (53.3\%) agreed that English should only be presented to cadets in the humanities track diploma. In contrast, $40 \%$ of them disagreed to this statement. The majority of the former cadets $(62.6 \%)$ disagreed with the college's policy in not introducing English to cadets with university degrees in science. They indicated that teaching English for security purposes should be introduced to cadets with university degrees in science such as medicine and engineering. Finally, the bulk of the former police cadets (81.2\%) disagreed with statement no. 11, which says there is no need to teach English to the cadets because they have studied it at the university level and they have good command of it. Despite this emphasis on teaching English at the college, the former police cadets were divided about the benefit they got from studying English at the college in developing their skills in English for security purposes. Half of them (50\%) indicated they did not benefit, whereas $43.8 \%$ said they did.

TABLE 2.

PERCENTAGES OF FORMER POLICE CADETS' PERSPECTIVES OF TEACHING ENGLISH AT KFSC

\begin{tabular}{|c|c|c|c|c|c|}
\hline Questionnaire Statements & SA & A & SD & $\mathrm{D}$ & $\mathrm{UC}$ \\
\hline 1. Teaching English for two hours per week is sufficient for the college's cadets. & 6.3 & 18.8 & 12.5 & 50 & 12.5 \\
\hline 2. Teaching English for one semester is enough for the college's cadets. & 12.5 & 18.8 & 6.3 & 62.5 & \\
\hline $\begin{array}{l}\text { 3. Increasing the number of hours for teaching English is necessary for the college cadets, so } \\
\text { that they can use English in their security jobs }\end{array}$ & 46.7 & 13.3 & 13.3 & 13.3 & 13.3 \\
\hline $\begin{array}{l}\text { 4. English should be taught to the college's cadets in the first and second semester in every } \\
\text { academic year. }\end{array}$ & 33.3 & 20 & 13.3 & 26.7 & 6.7 \\
\hline 5. There is a positive interaction between the cadets and the current English course. & & 25 & 25 & 25 & 25 \\
\hline $\begin{array}{l}\text { 6. The general content of the English course is consistent with the cadets' needs for English } \\
\text { for security purposes }\end{array}$ & & 81.3 & & 6.3 & 12.5 \\
\hline $\begin{array}{l}\text { 7. Teaching English in the college does not receive clear and practical support from those in } \\
\text { charge of education in the college }\end{array}$ & 6.3 & 43.8 & 12.5 & 18.8 & 18.8 \\
\hline $\begin{array}{l}\text { 8. The current English course in the college is weak in general due to the absence of the } \\
\text { necessary ingredients for its success }\end{array}$ & 6.3 & 62.5 & 6.3 & 6.3 & 18.8 \\
\hline $\begin{array}{l}\text { 9. Teaching English for security purposes should be limited only to cadets with university } \\
\text { degrees in humanities as used currently }\end{array}$ & 20 & 33.3 & 20 & 20 & 6.7 \\
\hline $\begin{array}{l}\text { 10. Teaching English for security purposes should be introduced to cadets with university } \\
\text { degrees in sciences such as medicine and engineering. }\end{array}$ & 6.3 & 56.3 & 12.5 & 12.5 & 12.5 \\
\hline $\begin{array}{l}\text { 11. There is no need to teach English to the college's cadets because they have studied it at } \\
\text { the university level and they have good command of it. }\end{array}$ & 6.3 & 12.5 & 43.7 & 37.5 & \\
\hline $\begin{array}{l}\text { 12. I benefited from studying English at the college in developing my skills in English for } \\
\text { security purposes. }\end{array}$ & & 43.8 & 25 & 25 & 6.3 \\
\hline
\end{tabular}

Note: The number of former police cadets is 16 .

\section{Current Police Cadets' Perspectives}


Table 3 below shows the percentages of current police cadets' perspectives of teaching English at KFSC. The current cadets' opinion of teaching English for two hours and for one semester is consistent with the teachers and former police cadets' perspectives. Half of the current cadets (50.8\%) disagreed with statement no. 1 that described teaching English for two hours and for one semester as sufficient. As a result of this disagreement, the majority of the current cadets (71.1\%) agreed that increasing the number of hours for English instructions would raise their English competence and help them use English in their assigned security sectors. The current cadets' positive attitude towards increasing the number of hours for English teaching can further be seen in their positive opinion (70.3\%) that English should be introduced to the cadets in the first and second semester in every academic year. It seems that is why more than half of the current police cadets $(58.7 \%)$ described the current English course as generally weak. With regard to statement 5 which is concerned with limiting the teaching of English to cadets with university degrees in humanities, more than half of the police cadets $(55.8 \%)$ did not agree with this statement. This is further can be seen in their opinion of statement no. 6. The majority of the cadets $(66.3 \%)$ agreed that English should be taught to the other cadets with university degrees in sciences such as medicine and engineering. Finally, the majority of the current police cadets (70.5\%) disagreed with the content of statement no. 7, which says that there is no need to teach English to the college's cadets because they have already studied it at the university level and they have good command of it.

TABLE 3.

PERCENTAGES OF CURRENT POLICE CADETS' PERSPECTIVES OF TEACHING ENGLISH AT KFSC

\begin{tabular}{|c|c|c|c|c|c|}
\hline Questionnaire Statements & SA & A & SD & $\mathrm{D}$ & $\mathrm{UC}$ \\
\hline 1. Teaching English for one semester and two hours per week is sufficient for the college's cadets. & 15.2 & 28.7 & 27 & 23.8 & 4.9 \\
\hline $\begin{array}{l}\text { 2. Increasing the number of hours for teaching English to the college cadets is necessary to raise } \\
\text { their competence and make them capable of using English in their security jobs. }\end{array}$ & 45.5 & 25.6 & 14 & 13.2 & 1.7 \\
\hline $\begin{array}{l}\text { 3. English should be taught to the college's cadets in the first and second semester in every academic } \\
\text { year, so that they can achieve competency in English. }\end{array}$ & 42.6 & 28.7 & 15.6 & 13.1 & \\
\hline $\begin{array}{l}\text { 4. The current English course in the college is weak in general due to the absence of the necessary } \\
\text { ingredients for its success }\end{array}$ & 33.1 & 25.6 & 9.9 & 4.6 & 27.3 \\
\hline $\begin{array}{l}\text { 5. Teaching English for security purposes should be limited to cadets with university degrees in } \\
\text { humanities as used currently }\end{array}$ & 18.3 & 19.2 & 27.5 & 28.3 & 6.7 \\
\hline $\begin{array}{l}\text { 6. Teaching English for security purposes should be introduced to cadets with university degrees in } \\
\text { sciences such as medicine and engineering. }\end{array}$ & 39.3 & 27 & 15.6 & 13.9 & 4.1 \\
\hline $\begin{array}{l}\text { 7. There is no need to teach English to the college's cadets because they have studied it at the } \\
\text { university level and they have good command of it. }\end{array}$ & 14.8 & 11.5 & 41 & 29.5 & 3.3 \\
\hline
\end{tabular}

To test the effect of university degree (science vs. humanities) on the cadets' responses, an independent-samples t-test was conducted. There was a statistically significant difference between the two groups with regard to statement $n$. 2. : increasing the number of English instruction hours. Police cadets with university degrees in humanities $(M=3.8386$, $\mathrm{SD}=1.12895)$ significantly differed from their counterparts with science degrees $(\mathrm{M}=4.2353, \mathrm{SD}=1.10613), \mathrm{t}=-1.974, \mathrm{p}$ $=0.051$. Similarly, cadets with university degrees in humanities $(M=3.8429, \mathrm{SD}=1.103049)$ significantly differed in their opinion of whether English should be taught in first and second semester from cadets with science degrees $(\mathrm{M}=4.2308, \mathrm{SD}=1.105933), \mathrm{t}=-2.032, \mathrm{p}=0.044$.

\section{Similarities and Differences among Stakeholders}

To test the similarities and differences between the three groups' opinions (teachers, former police cadets, current police cadets), a One-Way ANOVA test was employed. Table 4 below displays these questionnaire statements found in each group's questionnaire. There was a statistically significant difference between the three groups' means with regard to statement no. 1: Teaching English for two hours per week is sufficient for the college's cadets. The significance level is $0.035(p=.035)$, which is below 0.05. Post hoc comparisons using the Tukey HSD test indicated that the mean score for current cadets $(M=3.2623, S D=1.13402)$ was significantly different than the former police cadets $(M=2.5625$, $\mathrm{SD}=1.15289)$ and teachers $(\mathrm{M}=3.8000, \mathrm{SD}=.83666)$. However, the three groups did not differ in terms of the other four statements.

TABLE 4.

ANOVA ANALYSIS OF THE SIMILARITIES AND DIFFERENCES AMONG STAKEHOLDERS REGARDING TEACHING ENGLISH AT KFSC

\begin{tabular}{|c|c|c|c|c|}
\hline Questionnaire Statements & df & Mean Square & $\mathrm{F}$ & Sig \\
\hline 1. Teaching English for two hours per week is sufficient for the college's cadets. & 140 & 1.274 & 3.444 & $.035 *$ \\
\hline 2. Teaching English for one semester is enough for the college's cadets. & 140 & 1.292 & 1.422 & .245 \\
\hline $\begin{array}{l}\text { 3. Increasing the number of hours for teaching English to the college cadets is } \\
\text { necessary to raise their competence and make them capable of using English in } \\
\text { their security jobs. }\end{array}$ & 138 & 1.366 & 1.103 & .335 \\
\hline $\begin{array}{l}\text { 4. English should be taught to the college's cadets in the first and second semester } \\
\text { in every academic year. }\end{array}$ & 139 & 1.179 & 2.077 & .129 \\
\hline $\begin{array}{l}\text { 5. The current teaching of English in the college is weak in general due to the } \\
\text { absence of the necessary ingredients for its success }\end{array}$ & 139 & 2.456 & .522 & .594 \\
\hline
\end{tabular}

Note: The significance level is below 0.05 . 


\section{DISCUSSION}

The primary concern of this study was to evaluate the ESP course and English teaching at KFSC by means of the perspectives of three important stakeholders, namely the teachers, former police cadets and current police cadets. The overall goal behind this research project was to determine the appropriateness and effectiveness of the English ESP course and teaching at KFSC, and contribute to the improvement of the teaching of English to police cadets in Saudi Arabia. The analysis of the results has shown several violations of some of the principles involved in ESP course design and teaching, which may account for the participants' dissatisfaction with the ESP course and teaching at KFSC. These principles are discussed here.

\section{A. The Target Learners and Their English Needs}

In 2000, KFSC began to restrict its admission to university students with bachelor degrees in humanities and sciences. English is not introduced to university science students based on the unverified assumption that they had intensive English at the university level and hence they had no problem with communicating in English (Alhuqbani, 2014). This claim is groundless since it was based on intuition rather than research. Mackay and Palmer (1981) argued that many ESP well-intentioned programs have foundered because they were based on imagination rather than an objective analysis of the target learners' situations in which they will need to be able to use English. The research findings of this study showed that more than $73 \%$ of the current police cadets with university degrees in sciences agreed that English for security purposes should be introduced to them at KFSC. This finding is consistent with Alhuqbani's (2014) finding that police cadets of KFSC with university degrees in sciences expressed their need to study English for security purposes.

In ESP theory, learners are usually adults who have studied English for some time and therefore acquired some knowledge of English and are learning the language needed in a particular occupation or domain of knowledge in order to acquire professional skills and to perform particular job-related tasks (Pranckevičiūtė \& Zajankauskaité, 2011). That makes police cadets with university degrees in sciences the perfect candidates for the ESP program at KFSC because they have already developed some knowledge of general English and the English used in their university disciplines (e.g., engineering, medicine, computer sciences). The exclusion of this group of learners from any instructions in English for security purposes means that they would join their assigned security sectors after graduation without knowing and using important security terms and understanding texts. This exclusion of half of the college's police cadets from ESP instructions provides concrete evidence that the cadets' English needs were not taken into account prior to the teaching of English at KFSC. It further shows that teaching English at the college is not based on the needs of the cadets and their future security sectors. Needs assessment of the target learners' language needs is by definition the cornerstone of any ESP course design (Dudley-Evans \& St. John, 1998), and subsequent decisions involved in the design and development of an ESP program such as course objectives, instructional materials and teaching methodologies depend on it (Robinson, 1991; Shing \& Sim, 2012). It is therefore considered the first step in ESP program development (Hutchinson \& Waters, 1987; Robinson, 1991).

\section{B. Course Objectives}

The results showed clearly that the general objectives of teaching English to Saudi police cadets at KFSC must be formulated and made known to all teachers, so that they abide by them and work hard to achieve them. This may explain why the stakeholders in this study expressed their dissatisfaction with the current ESP course and teaching at KFSC. In ESP, formulating the course objectives follow the identification of the target learners' English needs. In this regard, Mackay and Mounford (1978, p. 17) argued that "as a result of the needs analysis, we should be able to draw up our objectives for the ESP course." Cunningsworth (1983) concluded that course objectives should be derived from the ESP learners' needs in order to help them accomplish their goals. Despite that the current textbook used to teach English for security purposes include four general objectives in the introduction, they do not represents the college's objectives from teaching English to its police cadets, and therefore no obligation can be made. In addition to taking into account the learners' English needs when writing up the course objectives, the security sectors' needs for English in the workplace should be should be carefully considered and translated into operational objectives. Since KFSC is the host academic institution of all Saudi would-be-officers, the college needs to formulate the ESP course objectives to reflect the needs of the security sectors where English might be used. The findings of previous studies (e.g., Alhuqbani, 2008, 2009, 2014) which assessed the English needs of police officers and cadets in Saudi Arabia can be used as a starting point to translate these needs into measurable objectives. Finally, formulating the course objectives should be developed according to one learning theory or more which can guide the teachers and administrators toward the accomplishment of the course objectives.

\section{Course Duration}

The three groups of participants (teachers, former police cadets, current police cadets) in this evaluation study were unsatisfied with the duration of the ESP course and teaching at KFSC. It is not theoretically clear and justified why the college devoted just two hours of English instructions per week in the last semester for its police cadets with university degrees in humanities, just before their graduation. A possible reason, yet not justified, is that the cadets are given many subjects in police and legal studies, which made English a secondary subject. 
It is generally known that ESP courses are short in duration, but dense in hours. They are designed to help students meet their job requirements as revealed by the needs assessment and translated in a set of operational learning objectives. Two hours per week are not enough to teach English for security purposes, especially for police cadets who had limited English instructions at the university level. Also, introducing English for security purposes in the fourth and last semester undermines the importance of English to police work. Police cadets in the fourth semester are almost officers since they are already assigned to security sectors with the rank of first lieutenants awaiting their graduation ceremony. This has negative impact on their motivation and attitudes for learning English (Alhuqbani, 2014).

\section{Course Evaluation}

The analysis of the teachers' questionnaire showed that there was no periodical evaluation of the English language course at KFSC to determine its appropriateness and objectives achievement. This explains why the course continues to exist for more than a decade without adjustment. Despite that program evaluation is an indispensable procedure in ESP because it determines whether the objectives of an ESP program have been met and guarantees the program's continuous improvement (Tsou \& Chen, 2014), it is usually avoided due to several factors. Batchman (1981) contended that lack of ESP program evaluations is due to the impression that it is carried out in an informal ad hoc manner, and that evaluation is rarely incorporated into the ESP course design. Other factors may include the short duration of ESP courses and the difficulties resulting from the execution of program evaluation which is time-consuming (Tsou \& Chen, 2014).

\section{Conclusion And Pedagogical Implications}

To conclude, this research revealed certain findings and pedagogical implications emerging from the analysis of the stakeholders' responses to the questionnaires. Overall, the findings indicated that the current ESP course is ineffective and inappropriate because it lacks the major principles associated with the teaching of English for specific purposes such as meeting the police cadets' actual needs and turning these needs into course operational objectives that can be measurable. The three groups of stakeholders agreed that teaching English for security purposes is very important to Saudi police cadets regardless of their previous English instruction at the university level. But, this importance is undermined by the way it is administratively introduced to the cadets. They expressed their strong disagreement with the course duration and timing.

The findings have important pedagogical implications to the teaching of English to police cadets at KFSC. They can be summarized in the following points.

1. The ESP course and teaching at KFSC should be redesigned and reshuffled to incorporate the English needs of the police cadets and their future security sectors.

2. The college's objectives and goals from teaching English to its police cadets should be written down and made clear to all parties involved in the teaching and learning process of English for security purposes. These course objectives and goals should be based on the English needs of police cadets and their future security sectors.

3. English for security purposes should be taught to all police cadets in the college irrespective of their previous instruction in English at the university level because they have not studied it for security purposes. It is the responsibility of the college administration to prepare the police cadets to function linguistically in their future security sectors.

4. The duration of the English course and its timing do not help the police cadets study and practice English for security purposes. Extra hours are needed. One way to do so is to introduce English to the cadets in every semester, not just in the final semester as it is done currently.

5. Both formative and summative evaluation should be conducted as part of the ESP course and teaching. The current ESP course and teaching at KFSC would not continue in the way it does now if formative and summative evaluation measurements were applied. Stakeholders can fix any problems with the ESP course through regular evaluation.

\section{REFERENCES}

[1] Aldossari, M. (1999). ESP textbook design: One evaluation. MA dissertation. Indiana State University.

[2] Alhuqbani, M. (2008). Identifying the English language needs of Saudi police officers. Ayn 2. 8, 1-43.

[3] Alhuqbani, M. (2009). A Study of Saudi police officers' motivations and attitudes for learning English as a foreign language. Journal of King Saud Univ., Lang. \& Trans 1. 21, 31-55.

[4] Alhuqbani, M. (2012). English for security purposes: Book 1. (2 ${ }^{\text {nd }}$ edn.). Alhomadi Press. Riyadh.

[5] Alhuqbani, M. (2014). An investigation of the English language needs, motivations, and attitudes of Saudi police cadets. International Journal of Applied Linguistics and English Literature 3.2, 201-213.

[6] Alqurashi, F. (2011). Teaching English for police purposes in Saudi Arabia: An exploratory study. Journal of Language Teaching and Research 2.4, 844-849. http://dx.doi.org/10.4304/jltr.2.4.844-849.

[7] Barnawi, O. (2011). Examining formative evaluation of an English for specific purpose program. Ph.D. dissertation, Indiana University of Pennsylvania.

[8] Batchman, L. (1981). Formative evaluation in specific purposes program development. In R. Mackay \& J.D. Palmer (eds.) Languages for specific purposes: program design and evaluation. Massachusetts, Newbury House, 106-116. 
[9] Brown, J. (1989). Language program evaluation: A synthesis of existing possibilities. In R. K. Johnson (ed.), The second language Curriculum. Cambridge: Cambridge University Press, 222-241.

[10] Cunningsworth, A. (1983). Needs analysis-a review of the state the art. System 11.2, 149-154.

[11] Dudley-Evans, T. \& St. John, M.J. (1998). Developments in ESP: A multidisciplinary approach. Cambridge: Cambridge University Press.

[12] El-Sakran, T. (2012). Evaluation of an English for specific purposes (ESP) book for students of Islamic and Arabic studies $\begin{array}{llllll}\text { Ayah. English for Specific Purposes World 34.12, 1682-3257. http://www.esp- } & \end{array}$ world.info/Articles_34/DOC/ESP_Book_Evaluation_Sakran.pdf (accessed 1/11/2013).

[13] Ghalandari, S. \& Talebinejad R. (2012). Medical ESP textbook evaluation in Shiraz Medical College. Education Research Journal 2.1, 20 - 29. http://www.resjournals.com/ARJ. (accessed 14/12/2013).

[14] Hossain, M. (2013). ESP needs analysis for engineering students: A learner centered approach. Presidency University 2.2 16-26. http://presidency.edu.bd/uploads/Article003.pdf (accessed 1/1/2014).

[15] Hutchinson, T. \& Waters, A. (1987). English for specific purposes. Cambridge: Cambridge University Press.

[16] Hwang, Y. \& S. Lin, (2010). A study of medical students' linguistic needs in Taiwan. The Asian ESP Journal 6.1, 35-58. http://www.asian-esp-journal.com/May_2010_Ebook.pdf (accessed 20/11/2013).

[17] Johnson, R. (1989). The Second language curriculum. Cambridge: Cambridge University Press.

[18] Kuppan, A. (2008). An evaluation of an English course for hospitality management in a tertiary institution. Ph.D. dissertation. University of Malaya.

[19] Lynch, B. (1996). Language program evaluation. Cambridge: Cambridge University Press.

[20] Mackay, R., \& A. Mountford (eds.) (1978). English for specific purposes. London: Longman Group Limited.

[21] Mackay, R., \& Palmer, J. (eds.) (1981). Languages for specific purposes: Program design and evaluation. Massachusetts, Newbury House.

[22] Munisamy, R. (1997). An evaluation of the Syllabus for English for commercial purposes. Ph.D. dissertation. University of Malaya.

[23] Patton, M. (1987). How to use qualitative methods in evaluation. Beverley Hills, California, Sage.

[24] Pranckevičiūtè, V., \& Zajankauskaitè, Z. (2011). Adjusting an ESP course to students' needs in tertiary education: A case study. Studies About Languages 21, 115-123. http://dx.doi.org/10.5755/j01.sal.0.21.2465 (accessed 1/11/2013).

[25] Qaddomi, H. (2013). English for specific purposes in Palestinian context: Determining EFL cadets' needs at AlIstiqlal University. Theory and Practice in Language Studies 3.7, 1110-1122. http://dx.doi.org/10.4304/tpls.3.7.1110-1122.

[26] Richards, J. (2001). Curriculum development in language teaching. Cambridge: Cambridge University Press.

[27] Richards, J. C., J. Platt, \& H. Weber (1985). Longman Dictionary of Applied Linguistics. Harlow: Longman.

[28] Robinson, P. (1991). ESP today: A practitioner's guide. New York: Prentice Hall.

[29] Sarem, S., Hamidi, H. \& Mahmoudie, R. (2013). A Critical look at textbook evaluation: A case study of evaluating an ESP course-book: English for international tourism. International Research Journal of Applied and Basic Sciences 4.2: 372-380, www.irjabs.com (accessed 24/12/2013).

[30] Sarudin, I., Mechraoui, A., Noor, Z., Ibrahim, E., Muhamed, Ibrahim, E, Muhamad, A. \& Abdul Malek, F. (2013). Stakeholders' perceptions of an English for occupational purposes course. World Applied Sciences Journal 21, 73-87, 2013. DOI:10.5829/idosi.wasj.2013.21.slt1.2140.

[31] Shing, S. \& Sim, T. (2011). EAP needs analysis in higher education: Significance and future direction. English for Specific $\begin{array}{llll}\text { Purposes } & \text { World } & 33.11, & 1-11 .\end{array}$ world.info/Articles_33/Doc/EAP\%20Needs\%20Analysis\%20in\%20Higher\%20Education_Shing.pdf (accessed 1/12/2013).

[32] Thompson, J. (2011). An evaluation of a university level English for tourism program. MA dissertation, Payap University. Thailand. http://www.esp world.info/Articles_31/An_Evaluation_of_a_University_Level_English_for_Tourism\%20Program_JennaThompson.pdf (accessed 1/1/2014).

[33] Tsou, W. \& Chen, F. (2014). ESP program evaluation framework: Description and application to a Taiwanese university ESP program. English for Specific Purposes. 33, 39-53. http://dx.doi.org/10.1016/j.esp.2013.07.008.

[34] Weir, C.J. \& Roberts, J. (1994). Evaluation in ELT. London: Blackwell.

Mohammed Nasser Alhuqbani is an associate professor and chair of the Department of Languages and Translation at King Fahd Security College, Riyadh, Saudi Arabia. He received his BS in English language and Literature in 1994 from the College of Education, King Faisal University in Alhasa, Saudi Arabia. He received his MA in Applied Linguistics/English Teaching in 1999 from Indian State University in Terre Haute, Indian, USA. He obtained his PhD in Applied Linguistics in 2004 from Boston University, Massachusetts, USA. Dr. Alhuqbani has published four books and several scholarly papers in local and international journals. His current research interests include, but not limited to, ESP, discourse analysis, forensic linguistics, bilingualism and language program planning and evaluation. 